LICENÇA CC BY:

Artigo distribuído sob os termos

Creative Commons, permite uso e distribuição irrestrita em qualquer meio desde que o autor credite a fonte original.

\section{A IMAGEM DO CORPO KAINGANG NOS CORAN-BANG-RÊ NO SÉCULO XVIII}

BODY IMAGE OF THE KAINGANG IN THE 18TH CENTURY CORANBANG-RE

LA IMAGEN DEL CUERPO KAINGANG EN LOS CORAN-BANG-RE DEL SIGLO XVIII

Giuliano Gomes de Assis Pimentel ${ }^{1}$

Luane Maciel Freire ${ }^{2}$

'Departamento de Educação Física, Universidade Estadual de Maringá, Maringá, PR, Brasil.

2Departamento de Teoria e Prática da Educação, Curso Artes Visuais, Universidade Estadual de Maringá, Maringá, PR, Brasil.

Artigo recebido em: 31/03/2020

Aprovado em: 15/11/2020

Resumo: O presente trabalho provém dos resultados obtidos durante a pesquisa de dissertação, a qual se debruçou em compreender a constituição de uma série de documentações iconográficas que retrataram um dos primeiros contatos registrados entre as populações indígenas Kaingang com os colonizadores, as quais estão localizadas no atual estado do Paraná. Portanto, objetiva-se analisar os delineamentos compositivos do corpo Kaingang traçados na sequência de 40 iconografias atribuídas ao engenheiro militar Joaquim José de Miranda no século XVIII, encomendadas para retratar a décima expedição militar ao mando da Coroa de Portugal aos sertões do Campos de Guarapuava nos anos de 1771-1772, com o desígnio de levantar estratégias para ocupar esta região. Tendo em vista que na vasta produção iconográfica sobre os indígenas no Brasil há poucos materiais que apresentam o registro histórico sobre os Kaingang no processo de colonização do Estado do Paraná, as questões norteadoras do respectivo trabalho consistem: Quais os interesses políticos e econômicos da colônia que impulsionaram a construção iconográfica corporal desta população? De que maneira o fog (não indígena ruim na língua Kaingang) produziu a imagem do corpo Kaingang no século XVIII, como ponto de fronteira no centro da dinâmica do contato e quais de tantos ângulos da história as imagens contam? Para a compreensão de tais problematizações, realizase uma análise documental pautada nas determinações materiais historicamente situadas na condição de produção das iconografias, assim se busca o diálogo entre os conhecimentos da área de Artes Visuais e Educação Física, por meio de aproximações entre os estudos da imagem e da sociologia do corpo. Em diálogo com a hermenêutica, interpretam-se as ilustrações fundadas no método iconológico 
desenvolvido pelo historiador de arte Erwin Panofsky (1892-1968), com a proposta de reconstrução do modo de produção do contexto histórico das imagens em três níveis de análise. Com as investigações, foi possível constatar que o corpo indígena situado nas relações de poder recebeu uma atenção especial dos colonizadores, visando a suas características e potencialidades a seu favor desde os primeiros contatos entre estas populações no século XVI. Na dada conjuntura, o corpo Kaingang no século XVIII, além de ser ponto de fronteira das relações de contato entre militares e Kaingang, foi visualizado como ponto de estratégia bélica para ser utilizado conforme os interesses coloniais deste período. As imagens a respeito deste corpo foram produzidas a partir da lógica militar, no momento em que a imagem era concebida como um meio de se projetar algo, isto é, os traçados e os riscos eram designados a um intuito, ocorrendo uma estreita relação entre o desenho e os interesses políticos. Perante a estas considerações, esta pesquisa constitui uma parte da história iconográfica do corpo Kaingang, auxiliando na compreensão histórica e nas demandas educacionais a respeito desta conjuntura.

Palavras-chave: Corpo - Iconografias; Kaingang; Militares; Campos Guarapuava.

Abstract: The work arises from the results obtained during the dissertation research, which focused on understanding the constitution of a series of iconographic documents that portrayed one of the first recorded contacts between the Kaingang indigenous people and the colonizers, in what is now the state of Paraná. It analyses the compositional outlines of the bodies of the Kaingang, drawn in a sequence of forty iconographies attributed to the military engineer Joaquim José de Miranda in the 18th century. De Miranda was commissioned to portray the tenth military expedition to the backlands of Campos de Guarapuava in 1771-1772, under the command of the Crown of Portugal, with the aim of raising strategies for the occupation of this region. Bearing in mind that among the vast iconographic production about the indigenous peoples of Brazil, there is very little material that presents the historical record of the Kaingang in the process of colonization of the state of Paraná, the guiding questions of this work were: What are the political and economic interests of the colony that prompted the iconographic body construction of this population? How did the fog (which in the Kaingang language means "a non-Kaingang person") produce the image of the Kaingang body in the 18th century, as a border point at the center of the dynamics of contact, and secondly, which of the many historical angles do these images portray? To answer these questions, a documentary analysis was carried out, based on material determinations historically situated in the production of iconographies. The aim was to construct a dialogue between knowledge in the field of Visual Arts and Physical Education by bringing together studies on image and sociology of the body. In dialogue with hermeneutics, illustrations based on the iconological method developed by the art historian Erwin Panofsky (1892-1968) are interpreted, seeking to reconstruct the mode of production of the historical context of images at three levels of analysis. Through this research, it was verified that the indigenous body, situated in the relations of power, was given special attention from the colonizers, aiming at its characteristics and potentialities in their favor from the time of the first contacts between these populations in the 16th century. In the given juncture, the Kaingang body, in the 18th century, in addition to being the frontier point of contact between the military and the Kaingang, was seen as a point of war strategy to be used according to the colonial interests of this period. The images of this body were produced from a military logic, at the moment when the image was conceived as a means of projecting something, i.e., the outlines and the risks were designated an intention, such that there is a close relationship between the drawing and the political interests of the time. In light of these considerations, this research constitutes a part of the iconographic history of the Kaingang body, furthering a historical understanding and meeting educational demands in relation to this situation. 
Keywords: Body - Iconographies; Kaingang; Military; Guarapuava Fields.

Resumen: El presente trabajo proviene de los resultados obtenidos durante la investigación de tesis, que se centró en comprender la constitución de una serie de documentación iconográfica que retrató uno de los primeros contactos registrados entre las poblaciones indígenas Kaingang con los colonizadores ubicados en el estado actual de Paraná. Por lo tanto, el objetivo es analizar los contornos compositivos del cuerpo de Kaingang dibujados en la secuencia de 40 iconografías atribuidas al ingeniero militar Joaquim José de Miranda en el siglo XVIII, encargado de retratar la décima expedición militar bajo el mando de la Corona de Portugal a las tierras de Campos de Guarapuava, en el 1771-1772, con el objetivo de plantear estrategias para ocupar esta región. Teniendo en cuenta que en la vasta producción iconográfica sobre los pueblos indígenas en Brasil hay pocos materiales que presenten el registro histórico sobre los Kaingang en el proceso de colonización del Estado de Paraná, las preguntas orientadoras del trabajo respectivo consisten en: ¿Cuáles son los intereses políticos y económicos de la colonia que impulsó la construcción del cuerpo iconográfico de esta población? ¿Cómo produjo la niebla (no un mal indígena en el idioma Kaingang) la imagen del cuerpo Kaingang en el siglo XVIII, como un punto fronterizo en el centro de la dinámica del contacto y ¿cuál de tantos ángulos de la historia cuentan las imágenes? Para comprender tales problematizaciones, se realiza un análisis documental basado en determinaciones materiales situadas históricamente en la condición de producción de iconografías, buscando así un diálogo entre el conocimiento en el campo de las Artes Visuales y la Educación Física, a través de aproximaciones entre estudios. de la imagen y sociología del cuerpo. En diálogo con la hermenéutica, se interpretan ilustraciones basadas en el método iconológico desarrollado por el historiador del arte Erwin Panofsky (1892-1968), con la propuesta de reconstruir el modo de producción del contexto histórico de las imágenes en tres niveles de análisis. Con las investigaciones fue posible verificar que el cuerpo indígena ubicado en las relaciones de poder, recibió atención especial de los colonizadores, apuntando a sus características y potencialidades a su favor desde los primeros contactos entre estas poblaciones en el siglo XVI. En la coyuntura dada, el cuerpo de Kaingang en el siglo XVIII, además de ser el punto de contacto fronterizo entre los militares y Kaingang, fue visto como una estrategia de punto de guerra para ser utilizado de acuerdo con los intereses coloniales de este período. Las imágenes sobre este cuerpo se produjeron a partir de la lógica militar, en el momento en que la imagen se concibió como un medio para proyectar algo, es decir, las huellas y los riesgos se asignaron a una intención, con una estrecha relación entre el dibujo e intereses políticos. En vista de estas consideraciones, esta investigación constituye una parte de la historia iconográfica del cuerpo de Kaingang, ayudando en la comprensión histórica y las demandas educativas con respecto a esta situación.

Palabras clave: Cuerpo - Iconografías; Kaingang; Militar; Campos Guarapuava.

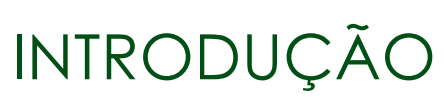

A análise deste artigo abrange parte dos resultados alcançados na pesquisa de Dissertação, a qual investigou um conjunto de desenhos iconográficos que representaram a etnia Kaingang no contexto colonial de tentativa de ocupação da região dos Campos de Guarapuava (atualmente localizado no estado do Paraná), em meados do Século XVIII. Este registro foi constituído por quarenta ilustrações de autoria de Joaquim José de Miranda e retrata o contato entre militares e os grupos Kaingang no ano de 1771 . Material que se diferencia 
dos demais produzidos neste mesmo período por enfatizar os personagens presentes neste acontecimento, além de atribuir um especial olhar à constituição física dos corpos indígenas.

Deste modo, objetivamos compreender a função que o desenho desempenhou no contexto de produção do respectivo material iconográfico, e o seu emprego como subsídio para o suporte de ocupação colonial a favor da Coroa Portuguesa em territórios brasileiros, tanto no processo de levantamento geográfico e populacional, com especial atenção ao corpo indígena neste processo. Apesar de a educação não ser o principal enfoque do trabalho, constatou-se que os aspectos historicamente estéticos no campo das disciplinas do ensino de arte no Brasil, em específico na organização curricular da educação básica, têm recebido pouco ou secundarizado tratamento em relação às demais. Consideramos que o entendimento histórico a respeito deste material iconográfico pode auxiliar na compreensão sobre este processo de ocupação colonial e sobre a importância que o corpo indígena ocupou nos registros imagéticos deste período, haja vista que há poucos materiais que apresentam o registro histórico sobre os Kaingang no processo de colonização do Estado do Paraná, em comparação com as diversas produções iconográficas sobre os indígenas no Brasil.

Destarte partimos das seguintes indagações: Quais os interesses políticos e econômicos da colônia que impulsionaram a construção iconográfica corporal desta população? De que maneira o fog (não indígena ruim na língua Kaingang) produziu a imagem do corpo Kaingang no século XVIII, como ponto de fronteira no centro da dinâmica do contato e quais de tantos ângulos da história as imagens contam? Para tal, realizamos uma análise documental pautada nas determinações materiais historicamente situadas na condição de produção das iconografias por meio de um diálogo entre os conhecimentos da área de Artes Visuais e Educação Física, lançando mão das aproximações entre os estudos da imagem e da sociologia do corpo.

Portanto, dividimos o presente manuscrito inicialmente com a contextualização histórica a respeito da etnia Kaingang no Paraná a partir das contribuições das literaturas históricas, antropológicas, etnológicas. Em seguida, discutimos os elementos da forma presente nas iconografias, nos quais descrevemos brevemente sobre o campo visual das estampas que compõem a sequência em questão e explicamos seu conteúdo geral. Apresentamos o contexto de produção das iconografias a respeito da conjuntura das expedições militares de conquista aos Campos de Guarapuava, 1768 a 1774. Localizamos historicamente sobre a função e o estilo do desenho neste determinado momento, em especial a respeito da influência do estilo cartográfico no estilo das estampas produzidas pelos engenheiros militares. Por final, discorremos sobre o resultados das análises em relação à construção da imagem do corpo Kaingang no século XVIII tanto como um ponto de fronteira das relações de contato entre militares e Kaingang, como estratégia bélica para ser utilizada conforme os interesses coloniais deste período. 


\section{O POVO KAINGANG: RESISTÊNCIA E LUTA NO HISTÓRICO DO CONTATO}

A sequência de 40 iconografias que retratou a população Kaingang no século XVIII foi produzida pelo engenheiro militar Joaquim José de Miranda, como uma encomenda para ilustrar o contato entre tais indígenas com os militares que realizaram a primeira expedição colonial à região dos sertões do Tibagi nos campos de Guarapuava, pertencente ao atual Estado do Paraná. Neste episódio da história, é possível constatar a luta e a resistência deste povo ao avanço do processo de colonização de seus territórios.

Neste sentido, Mota (2009) contextualiza sobre o histórico tanto da presença Kaingang na respectiva localidade, como do contato com as outras populações. A ocupação desta etnia na região data tempos remotos constados em diversas informações, desde relatos de viajantes, relatórios de expedições militares, científicas, governamentais, ofícios, além de evidências arqueológicas.

Por ocasião da chegada dos primeiros europeus no início do século XVI já se encontravam na região as populações indígenas conhecidas hoje de histórias. São elas os Guarani e Xetá do tronco linguístico Tupi, e os Kaingang e Xokleng do tronco linguístico Macro-Jê. (MOTA, 2009, p. 81).

O autor esclarece que, neste primeiro momento, os Guarani conquistaram gradualmente os vales e rios da região, o que levou os Kaingang migraram para o centro-sul e passarem a ocupar os territórios interfluviais. Entretanto, no final do século XVII, com a redução da população Guarani, os Kaingang retornaram a expandir-se pelo Paraná. Mas foi somente no século XVIII que ocorreram as primeiras expedições coloniais, e devido aos registros escritos, possibilitaram divulgar as toponímias atribuídas pelos Kaingang para denominar seus territórios.

Koran-bang-rê (campos de Guarapuava); Krei-bang-rê (campos de Palmas); Kampo-rê (campo Erêsudoeste); Payquerê (campos entre os rios Ivaí e Piquiri hoje nos municípios de Campo Mourão, Mamborê, Ubiratã e outras adjacentes); Minkriniarê (campos de Chagu, oeste de Guarapuava no município de Laranjeira do Sul); campos de Inhoó (em São Jerônimo da Serra). (MOTA, 2009, p. 84).

A primeira toponímia, "Koran-bang-rê (campos de Guarapuava)", corresponde à região retratada pela respectiva sequência iconográfica, que estampou parte da história sobre as expedições comandadas pelo tenente-coronel Afonso Botelho, uma ofensiva que perseverou por sete anos em explorar os rios Iguaçu e Ivaí, além de suas adjacências, totalizando seis anos de expedição, empenhadas ao longo dos anos de 1768 a 1774. Este encontro entre os Kaingang e os militares, que se iniciou aparentemente de forma pacífica, em seu desenrolar foi demarcado por conflitos e embates que culminaram na morte de alguns membros da expedição, como resposta por parte dos Kaingang de uma forte resistência em relação à ocupação de seus territórios. "Finalmente, em 1774, Botelho retira-se da região sem conseguir seu objetivo: conquistar os campos de Guarapuava" (MOTA, 2009, p. 129). O autor frisa que as ações dos povos indígenas como atuações políticas demonstram os distintos objetivos das partes diante do contato: 
Enquanto o objetivo do governo era reduzir os bárbaros à 'civilização', introduzi-los no grêmio da Igreja e fazê-los respeitar o rei, o dos índios era expulsar os intrusos de suas terras, fossem os fazendeiros e seus gados, fossem os viajantes que cruzavam seus territórios ou as forças armadas da colônia. (MOTA, 2009, p. 131).

Tal resistência Kaingang pode ser identificada já nos registros sobre os primeiros contatos entre as populações indígenas e os colonizadores no Paraná. Relações impulsionadas pelas necessidades dos primeiros navegantes aportarem pelo litoral da região, devido à necessidade de abastecerem seus navios com água, lenha e mantimentos em geral, além de a região compor parte do percurso para o império Inca das primeiras expedições portuguesas e espanholas, e também pelos naufrágios que aconteciam próximos do local (MOTA; NOVAK, 2008).

Dessa maneira, os autores esclarecem que, a partir do contato dos europeus com a população Guarani, os viajantes obtiveram informações a respeito da existência de grandes riquezas no oeste paranaense. Logo, resultam nas primeiras expedições em conjunto com estes índios pelo interior do território, em busca das terras que continham prata e ouro em abundância, isto é, o princípio do processo de conquista dos territórios indígenas do interior no atual estado do Paraná.

Neste momento, surgem as primeiras menções, ainda que indiretas, das populações Kaingang no Paraná, decorrentes das primeiras viagens terrestres dos europeus pelo interior da Região Sul do Brasil. Dentre estas, destaca-se o trajeto de Alvaro Nuñes Cabeza de Vaca. Mesmo que o viajante não tenha se defrontado pessoalmente com os Kaingang, durante todo o percurso de sua viagem desvia dos territórios desta população. Mota e Novak (2008) elucidam que Dom Alvaro Nuñes Cabeza de Vaca vem para Brasil comandar a província do Paraguai a mando do rei da Espanha, aportando na ilha de Santa Catarina, e, no fim de 1541, parte da foz do Rio Itapucu em direção a Assunção.

Durante a expedição, foi acompanhado por centenas de índios Guarani. A cada novo território que ingressava, a expedição dispensava os acompanhantes do território anterior e, mediante pagamentos em espécie (machados, contas, etc.), integrava novos guias para o percurso seguinte. (MOTA; NOKAK, 2008, p. 38).

Os autores, ao descreverem o percurso de Cabeça de Vaca, apontam que a expedição passou pela Serra do Mar até o rio Negro na altura do rio Negrinho, no estado de Santa Catarina, e desceu onde o rio Iguaçu desemboca, contudo subiu até certa altura deste rio para alcançar o rio Tibagi, dirigindo-se para o oeste, até chegar ao rio Ivaí e ir em direção ao sudoeste, para alcançar novamente o rio Iguaçu. Este caminho maior foi feito intencionalmente para desviarem do território Kaingang. Perante tais questões, os autores consideram o relato de Alvar Nunez Cabeza de Vaca crucial em razão de suas descrições sobre os caminhos percorridos pertencentes a diferentes grupos Guarani e, principalmente, ao desvio realizado dos territórios Kaingang em Palmas e Guarapuava. Além disso, trata-se do primeiro documento a informar que a maior parte da região estava habitada e também mostra a divisão política destes grupos com a mesma matriz cultural. 
[...] - ainda que indiretamente, o trajeto de Cabeça de Vaca, devido à imensa volta que a expedição fez não seguindo o vale do rio Iguaçu, dá-nos uma noção da extensão do território dominado pelos Kaingang nos Kora-bang-rê (Campos de Guarapuava). (MOTA; NOVAK, 2008, p. 39).

Diante das considerações dos autores, visualizamos o aspecto de beligerância presente nos Kaingang, visto que, a todo o momento, Cabeza de Vaca desvia de seus territórios. O que será...

\section{O CICLO DE MIRANDA: ELEMENTOS FORMAIS E DE PRODUÇÃO DO CONTEXTO DAS ICONOGRAFIAS}

O objeto de análise consiste na sequência de 40 ilustrações que acompanham um documento ${ }^{1}$, destinado à Rainha de Portugal ${ }^{2}$, e escrito por Afonso Botelho de S. Paio e Sousa ${ }^{3}$ a respeito de expedições organizadas aos sertões do Tibagi ao longo dos anos de 1768-1774. A referida expedição ocorreu na capitania de São Paulo, durante o governo de D. Luís Antônio de Sousa Botelho Mourão4.

O contexto histórico em que se encontram as respectivas iconografias abrange o período colonial brasileiro, especificamente durante o governo de D. Luís Antônio, sob a capitania de São Paulo, a partir de 1765. Nesta conjuntura, as expedições aos Koran-bang-rê (Campos de Guarapuava) compreenderam uma das diretrizes atribuídas a D. Luís pelo do governo central, a Coroa de Portugal, que visava defender a Região Sul da ameaça de ocupação espanhola e a exploração desta região. Para tal, a capitania obteve um corpo de tropa formada por seis Companhias de Infantaria e Artilharia. No quadro de militarização do governador, constava o seu ajudante de Ordens e primo, Afonso Botelho de Sampaio Souza, autor do documento sobre as expedições do Tibagi e comandante. O intento deste governo, na exploração territorial e na conquista de "novos sertões", compreendia as áreas do Iguatemi, Tibaji e a dos Campos de Guarapuava, local que foi retratado nas ilustrações, atualmente região pertencente ao estado do Paraná (BELLOTTO, 2007).

O chamado 'sertão do Tibagy' e os Campos de Guarapuava aparecem freqüentemente juntos na documentação; são áreas contíguas. Pela primeira designação compreende-se todo o vale do rio Tibagi, do rio Ivaí, a serra de Apucarana, até os cursos do rio Corumbataí e Mourão. Os Campos de Guarapuava ficam a sudoeste desta áreas, atingindo o curso do rio Iguaçu. (BELLOTTO, 2007, p. 136).

A autora esclarece que a expedição era de responsabilidade do governo de São Paulo à custa da fazenda real e organizada por Afonso Botelho. A respeito da documentação iconográfica, Belluzzo e Piccoli (2003) esclarecem que falta informação sobre o histórico desta obra, pois não se sabe quem a teria guardado e em que momento teria surgido no mercado de arte. Somente há referência da proveniência da série atribuída a Joaquim José de Miranda em um catálogo referente a uma das maiores casas de leilões mundiais a Sotheby's, especificamente a de Nova lorque, datado em 1985. Tais estampas foram registradas como perdidas por cerca de 200 anos: "presumably lost for over 200 years". Atualmente, este material 
pertence à coleção particular de Beatriz e Mário Pimenta Camargo, colecionadores de arte que adquiriram a obra no referido leilão. Em 2003, as ilustrações foram publicadas pela editora BNP Paribas, com apoio da Lei de Incentivo à Cultura.

As 40 iconografias, também conhecidas como o "ciclo de Miranda" ${ }^{5}$, foram acompanhadas de um relatório, intitulado "Notícia da Conquista e descobrimento dos sertões do Tibagi" 6 , que contém as legendas e as narrações dos acontecimentos retratados em cada estampa. Relatadas de maneira pormenorizada, demonstram a leitura dos militares diante daquela dada conjuntura. Assim, é possível observar nas descrições das imagens a divisão das estampas por meio de 10 sequências que descrevem os acontecimentos da expedição por data. Para a compreensão sobre o conteúdo das imagens e o estilo de sua produção, primeiramente descrevemos uma breve síntese de cada sequência por meio da observação dos elementos formais das estampas, nos quais são percebidos, pelo nosso campo visual, as cores, as linhas e os volumes constituintes das imagens em questão, juntamente embasados nas informações contidas do respectivo relatório. Em seguida, lançamos mão de referências históricas que explicam as normas e os padrões aplicados na produção das iconografias que descrevem o seu estilo artístico. A $1^{\circ}$ sequência é composta por 5 estampas que retratam isoladamente homens e mulheres Kaingang, constitui uma exceção em relação às demais, pois somente apresentam os sujeitos ali retratados sem referências a paisagens ou alguma ação que poderia envolver tais indivíduos. O fundo foi somente preenchido por uma cor amarelada, elemento crucial para destacar a imagem dos indígenas. Frente a este apelo visual, fica clara a intencionalidade dos expedicionários: descrevê-los, principalmente as características dos seus corpos.

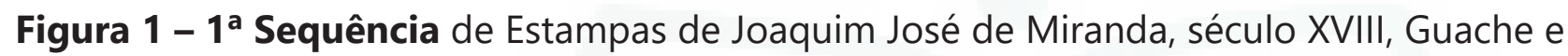
Aquarela, $42,5 \times 55 \mathrm{~cm}$

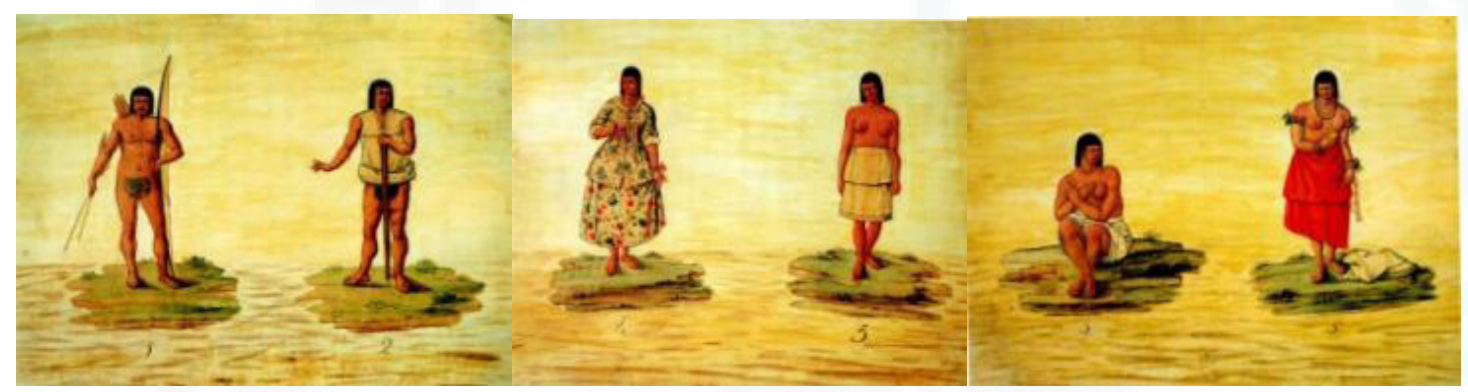

Fonte: Belluzzo et al. $(2003)^{7}$.

A $2^{a}$ sequência apresenta o primeiro encontro da expedição entre Kaingang e militares ocorrido nos Campos de Guarapuava, datado em 16 de dezembro de 1771. Ilustra a primeira parte do relatório, seguida pelas imagens de número 6, 7, 8, 9, 10, 11 e 12. 
Figura 2 - 2a Sequência de Estampas
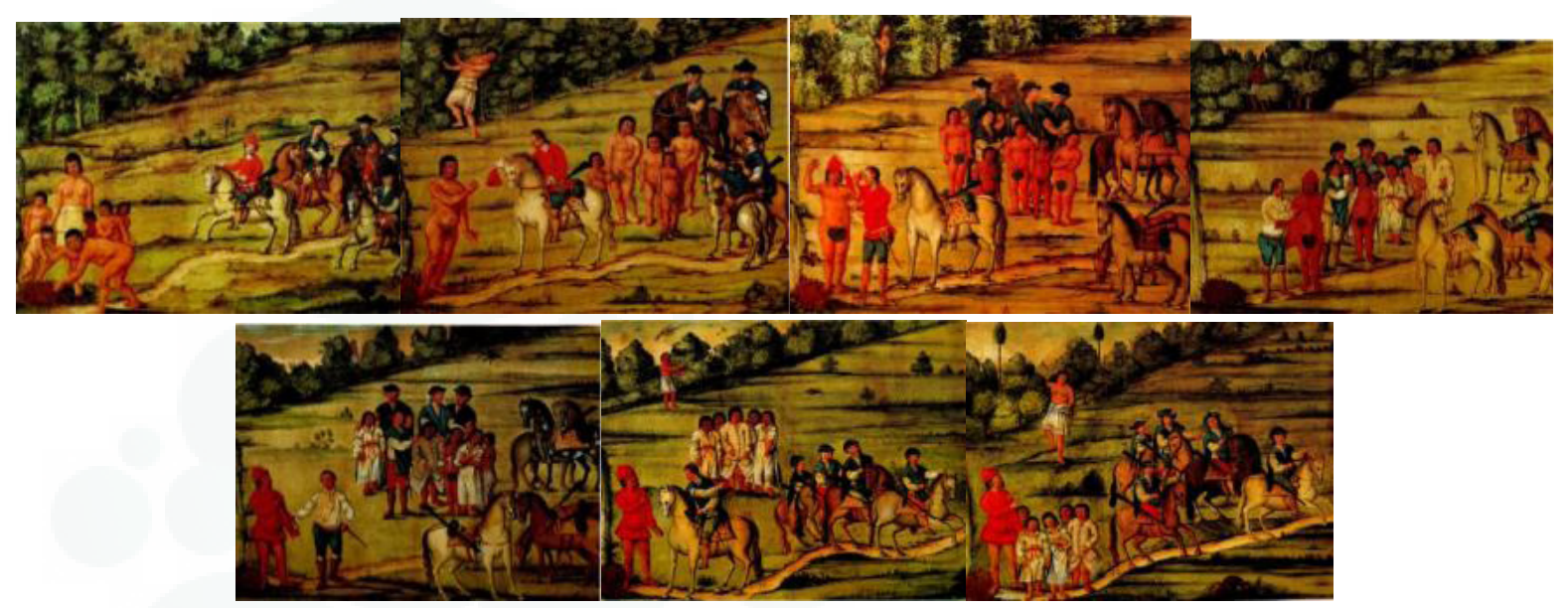

Os acontecimentos da $3^{a}$ sequência possuem, como cenário, um emã Kaingang (tipo de habitação), que fora abandonada pelos indígenas, local em que os militares ficaram acampados. Descreve o momento de reconhecimento da região realizado pelo tenente-coronel Afonso Botelho e sua tropa, o que levou a encontrar esta habitação próximo a um riacho e assim construir um alojamento provisório para os militares se instalarem. Além de apresentar o acampamento, mostra a visita de alguns Kaingang ao local. Os fatos se apresentam de acordo com a sucessão de eventos vivenciados pela expedição.

Figura 3 - 3a Sequência de Estampas

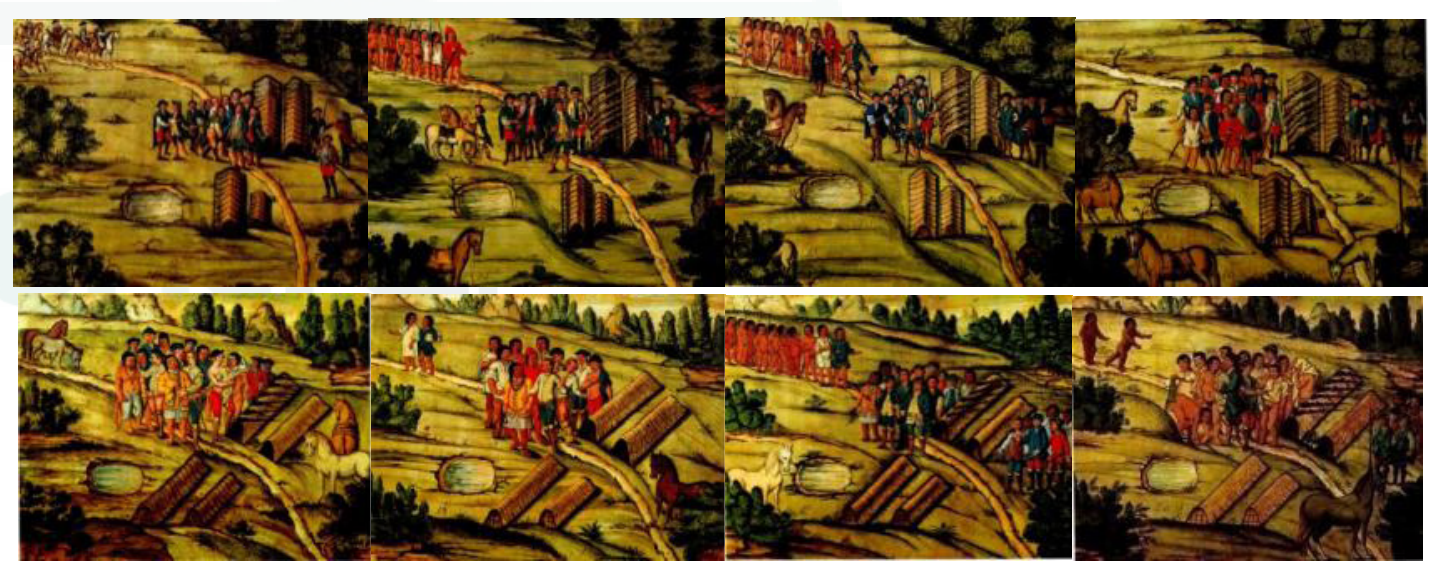

A $4^{a}$ sequência consiste na continuação do primeiro encontro entre os militares e os indígenas. As cenas que sucedem se iniciam na estampa 22 e terminam na estampa 26, em específico ilustram a visita dos militares ao alojamento dos Kaingang, com a finalidade de conquistar a confiança deste povo. 
Figura 4 - 4a Sequência de Estampas

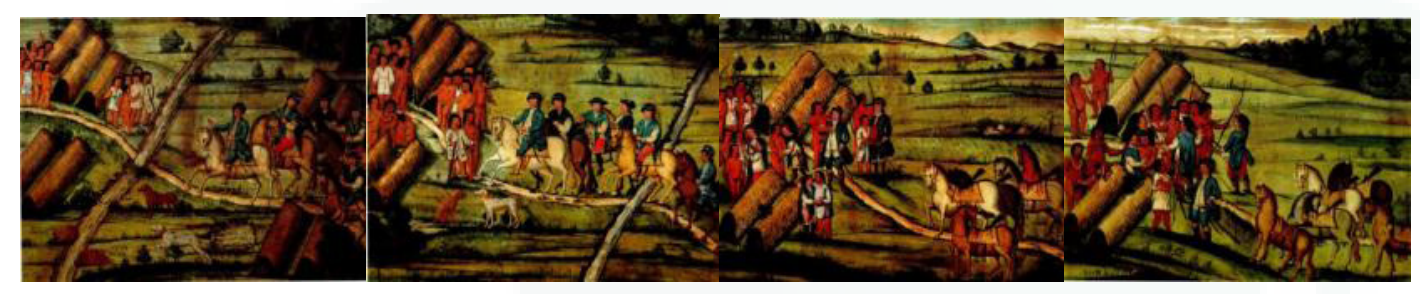

As estampas que abarcam da $5^{a}$ à $10^{a}$ sequência compõem os últimos episódios do contato entre Kaingang e militares. Iniciam na estampa vinte e sete e terminam na estampa quarenta, representando cerca de um mês de contato e correspondendo a data do relatório correspondente aos acontecimentos de 18 de dezembro do ano de 1771 a 11 de janeiro do ano de 1772. O cenário da maioria das imagens retrata o porto dos militares, próximo ao rio Jordão, uma espécie de acampamento que contém todos os recursos necessários para a expedição. Provavelmente seja o local em que toda a tropa permaneceu alojada. Em sua maioria, as estampas ilustram a aproximação dos indígenas a este acampamento, com exceção de três estampas, as de número 31, 36 e 38. Nestas imagens foi retratada a forma como os Kaingang progressivamente atacaram a expedição e expulsaram os militares de seus territórios, o que culminou na morte de parte dos integrantes da expedição. Conforme Mota (2009), a aproximação entre Kaingang e militares compreendeu uma das táticas de guerra dos primeiros, os quais buscaram observar a posição de defesa dos militares. Neste processo, concluíram que era impossível atacar no acampamento, logo se apropriaram de outras estratégias, como o envenenamento dos bolos de milhos que ofereceram para os militares, além de colocaram as mulheres Kaingang para seduzir os militares e os convenceram a sair do porto e atravessar o outro lado do rio até seus alojamentos. Neste momento, longe de seus acampamentos, os militares caíram em uma emboscada e foram atacados com flechas pelos Kaingang, acarretando na morte de seis membros da expedição.

Não foram retratadas as emboscadas em si nas estampas, mas sim o movimento de aproximação dos Kaingang ao acampamento militar no processo de observação; consecutivo afastamento de alguns militares do alojamento para caçar, os quais foram surpreendidos por alguns indígenas; os membros da expedição já mortos longe do acampamento cercado por vários indígenas; o encontro dos cadáveres pela tropa; e, por final, os militares se retirando e indo embora do acampamento. 
Figura 5- Da $5^{a}$ à $10^{a}$ Sequência de Estampas
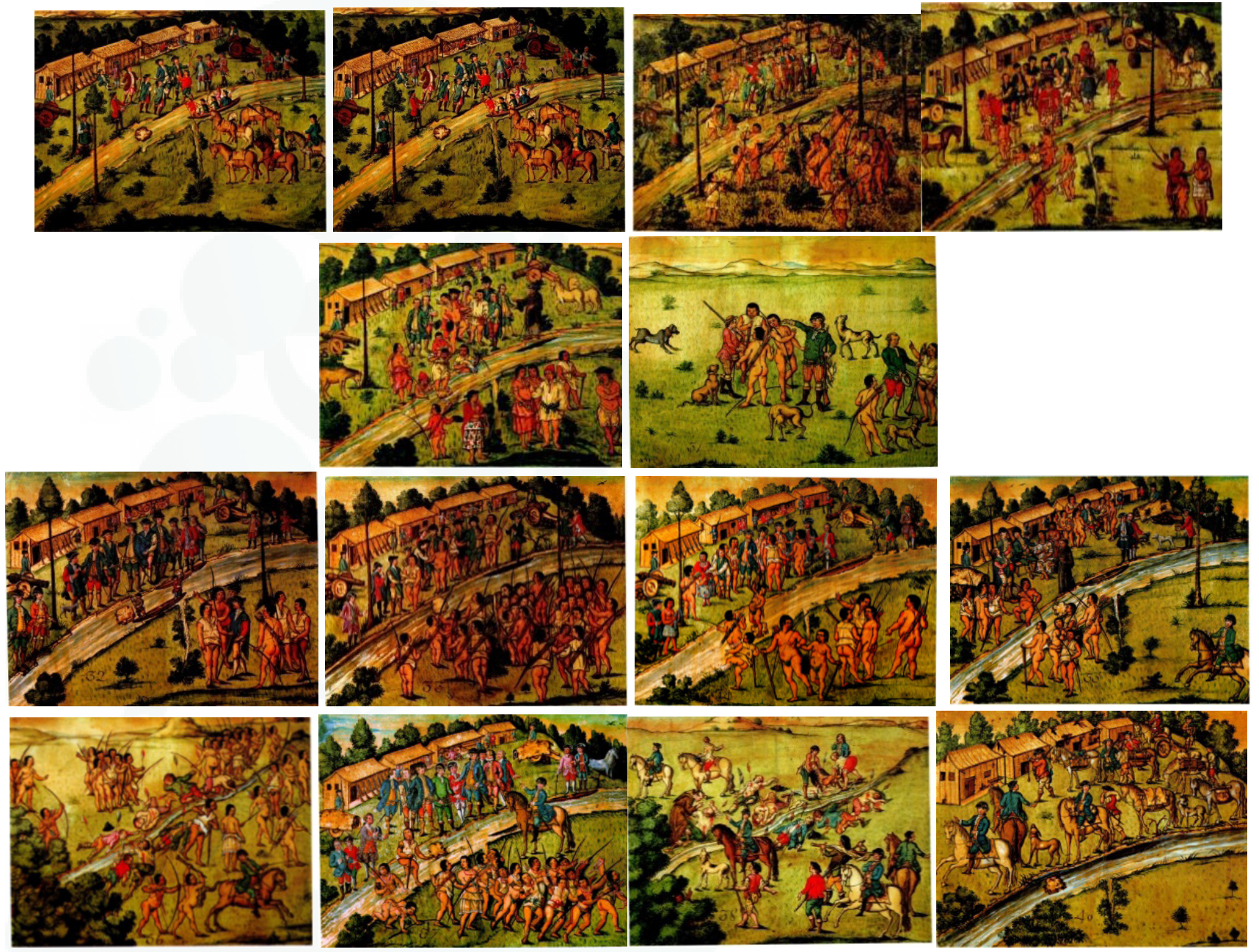

Vale destacar a falta da estampa trinta e nove, a qual foi extraviada e até hoje nada se sabe sobre seu paradeiro (SEVCENKO; 2003). Contudo, no relato contém sua descrição, "39. Chegam os camaradas mortos ao abarracamento, e sepultam todos em v̂a cova ${ }^{8 "}$. O desaparecimento somente desta ilustração de todo o conjunto é algo intrigante, não se sabe nada sobre as razões deste fato. No catálogo somente há as informações de Belluzzo, Piccoli (2003), a cena desapareceu e não estava conservada com o conjunto. Tudo indica que ela apresentava o sepultamento dos militares mortos durante a expedição e a construção de uma cruz cristã como símbolo de boa-fé da expedição.

Além de tais informações, Mota (2009) contextualiza que, após o desfecho do ataque, os Kaingang começaram a matar os bois, a perseguirem os militares e também mataram os cavalos. Desse modo, as estampas retrataram a vitória dos Kaingang sob os militares, nesta tentativa de conquista dos Campos de Guarapuava. Isto é, demonstra a resistência e a luta deste povo na proteção de seus territórios por meio de táticas estrategicamente eficazes de defesa.

Tendo em vista que a conjuntura de produção das iconografias abrangeu as normativas atribuídas ao governo de D. Luís Antônio de Sousa Botelho Mourão, também conhecido como Morgado de Mateus, na capitania de São Paulo pela Coroa Portuguesa, especificamente para cumprir a atribuição da defesa da Região Sul contra a ameaça de ocupação espanhola na região 
dos Campos de Guarapuava, sertões, apresentamos uma breve contextualização histórica a respeito dos desígnios da respectiva expedição. Bellotto (2007) esclarece que, em meados do século XVIII, dentre as preocupações da Coroa, encontrava-se a segurança das capitanias sulinas do Estado do Brasil contra as ofensivas espanholas. Assim, era necessário pensar em uma ação bélica em relação a tais ataques. Para tal, a Metrópole delega ao Governador de São Paulo a militarização da capitania, tanto para a defesa do Sul como para as fronteiras Oeste, além de ampliar os domínios de Portugal.

Segundo a autora, as instruções passadas pela Coroa a Morgado de Mateus continham os procedimentos de como Portugal pretendia consolidar o domínio das Capitanias do Brasil, tanto no estabelecimento da economia interna do estado de São Paulo, como a defesa de seus territórios contra a ameaça dos inimigos, isto é, o combate aos espanhóis. A defesa das fronteiras foi a função mais destacada nos ofícios e nos documentos dirigidos ao governador de São Paulo pela Metrópole. Assim foi a conjuntura que a expedição se encontra, nas medidas planejadas para o fortalecimento e estabelecimento do domínio português nos territórios brasileiros que envolviam as populações indígenas. A tática do governo de Portugal pretendia aproveitar tanto os paulistas como os indígenas que habitavam as regiões do Sul para fortalecer as fronteiras dos domínios espanhóis. Na realidade, visava que constituíssem a principal força e riqueza de defesa das fronteiras portuguesas. Deste modo, almejava civilizar os índios e trazê-los em favor de Portugal e assim colocá-los contra os jesuítas. O projeto buscava utilizar os indígenas que já estavam no lado português para que eles persuadissem seus iguais das vantagens nesta escolha. Com isso, foi atribuído ao vice-rei incentivar os estabelecimentos de índios livres e convencer os habitantes dos sertões a serem favoráveis a esta condição (BELLOTTO, 2007).

Contudo, o desfecho não foi o esperado pela Coroa, os Kaingang reagiram de maneira estratégica, o que expressa a beligerância como uma constante reação deste povo perante as tentativas de domínio colonial de seus territórios. Mota (2009), ao discutir a respeito das táticas de guerras como formas de lutas dos Kaingang, traz a questão da situação colonial9: "[...] a violência do colonizador contra o colonizado tem mão dupla: a qualquer momento o colonizado reage, também de forma violenta, contra aquele que o oprime [...]" (MOTA, 2009, p. 114). Ao enfatizar que o corpo colonizado demonstra tal aspecto de violência como reação à violência maior que o atinge, o autor discorre sobre a expedição, apontando que o objetivo dos Kaingang consistia em expulsar os invasores de suas terras. O caráter de resistência deste grupo foi desenvolvido a partir das relações conflituosas vivenciadas. "Os choques e escaramuças contra os brancos e as tribos inimigas foram uma constante na Vida Kaingang desde a chegada dos europeus" (MOTA, 2009, p.113). Desde então aprimoraram suas técnicas de combates, táticas bélicas, maneiras de ataque sob o inimigo: "[...] de guerrilhas, de emboscadas, e ataques capaz de fazer frente a um inimigo muito superior a eles [...]" (MOTA, 2009, p. 113). Formularam estratégias para atingir sua finalidade com a décima expedição aos Campos de Guarapuava. Para isso, buscaram reconhecer e identificar quem eram os invasores, quais eram suas forças bélicas. 
As 40 estampas contam por meio do desenho os acontecimentos que sucederam na expedição organizada aos sertões do Tibagi ao longo dos anos de 1768-1774, tanto sobre as estratégias de ocupação territorial da Região Sul por parte da colônia, como a respeito das táticas de resistências empregadas pelos colonizados, no caso os Kaingang. Em ambos movimentos o corpo torna-se alvo desses processos e de tais olhares.

Em relação ao intento dos colonizadores, a documentação iconográfica referente à expedição consiste em um registro sobre as expedições ao Tibagi e aos Campos de Guarapuava, das quais eram parte das estratégias de Morgado de Mateus para expandir os domínios territoriais portugueses e ao mesmo tempo buscar estabelecer um povoamento da região por meio da catequização dos índios. Tática que visava impedir a expansão espanhola nestes territórios. Além disso, para o governador, a ocupação destes territórios percorridos pela expedição Ihe daria notoriedade perante a Coroa Portuguesa. Entretanto, a Coroa compreendia tal ação como secundária e afirmava que a função do governador deveria ser defender diretamente o Rio Grande do Sul. Até 1771 a Coroa incentivou tais expedições, porém não havia como expender esforços com a defesa ao Rio Grande e com as expedições de conquista nos sertões. Além disso, no que diz respeito às expedições ao Tibagi e aos Campos de Guarapuava, foram efetuadas onze expedições de tentativa de conquista, entre os anos de 1768 e 1773, e pelo que podemos observar, sem sucesso em relação ao estabelecimento de povoamento na região em razão dos ataques indígenas. (BELLUZZO; PICCOLI, 2003).

Em convergência com as táticas da Coroa, as estampas foram produzidas de acordo com a função que o desenho era empregado, como parte ativa do projeto de conquista da América portuguesa. Isto é, utilizado como uma forma de estratégia política. Belluzzo e Piccoli (2003) esclarecem tal finalidade em dois momentos notórios durante sua ocupação sob a América. Primeiro, no ciclo de descobertas do domínio dos mares e terras, por meio de planos e riscos aplicados a fins práticos, com os cartógrafos portugueses que foram diferenciados no ofício de traçar mapas e cartas para orientação dos mares no século XVI. E, no segundo momento, no ciclo dos engenheiros militares emerge o engenheiro desenhista. Sua função consiste em delimitar e em proteger os limites geográficos da América portuguesa. Além de abrir caminhos e traçar fronteiras nas cartas, também projeta fortificações, já que "[...] o desenho adquiriu dimensão constitutiva da história e alcançou notável expressão" (BELLUZZO; PICCOLI, 2003, p. 44).

Para as autoras, a confecção das estampas de José Joaquim de Miranda está inserida nesse segundo momento, denominado com estilo cartográfico, apesar de não existir maiores informações sobre esta figura e também não se ter notícia da existência de outras obras de sua autoria. Sabe-se que a linguagem do desenho cartográfico foi renovada a partir do reinado de D. João $\mathrm{V}$, com a sistematização dos signos cartográficos, até o período pombalino e de D. Maria I., em especial, no último quartel do século XVIII. No mesmo momento de confecção das estampas há uma geração de luso-brasileiros que se formam como naturalistas em Coimbra, "[...] para os quais o desenho seria um meio de inventariar povos e recursos naturais" 
(BELLUZZO; PICCOLI, 2003, p. 44). Tais desenhistas agiam concomitantes aos engenheiros militares nas explorações científicas e viagens demarcatórias no vice-reinado do marquês de Lavradio entre 1779 a 1790.

A respeito do desenho dos engenheiros militares, Bueno (2011) analisa o processo de formação e a metodologia destes profissionais a partir do papel que exerciam "[...] como mediadores das ações oficiais da Coroa no processo de colonização do Brasil - o alcance desses 'desenhos desígnios' como produtos vetores de uma ação colonizadora" (BUENO, 2011, p. 25).

Deste modo, o desenho, ao servir como instrumento de domínio dos territórios conquistados, foi progressivamente aprimorado por técnicas de projeto e representações visuais devido aos investimentos de Portugal a esta modalidade. Segundo Bueno (2011), os engenheiros militares a serviço da Coroa eram incumbidos em confeccionar mapas (geográfico, corográfico e topográfico) para concretizar a conquista das terras encontradas, especificamente realizavam levantamentos condizentes ao conhecimento e à definição do território. Durante o Reinado de D. João V (1706-1750) foram aplicadas técnicas renovadoras nos desenhos cartográficos, padrões, estilos e procedimentos que provavelmente influenciaram de modo direto a confecção das estampas. Momento marcado pela publicação de dois tratados sobre o assunto: "Tratado do modo o mais fácil e o mais exacto de fazer cartas geográficas, assim de terra como de mar, e tirar as plantas das praças (1722)" e "O Engenheiro Portuguez (Tomo I, 1722)". Ambos foram os primeiros tratados publicados em Portugal sobre o desenho do engenheiro militar. Apesar da existência de outros gêneros de tratados, nenhum deles abordaram sobre o desenho como este, que estabeleceu convenções e normas uniformes para a "representação gráfica (arquitetônica e cartográfica)".

Outra questão relevante, observada pela autora, é a definição atribuída ao desenho. Neste contexto, o desenho, muito influenciado pelo movimento Renascentista ${ }^{10}$, era entendido como um recurso para designar uma função, isto é, o traçado e o risco são relacionados à expressão de um projeto a se realizar, ou seja, um desígnio, um intuito de um projeto. Portanto, há uma estreita relação entre o desenho e os interesses políticos, no caso os desígnios da Coroa Portuguesa. O desenho passa a ser visto como ciência, isto é, uma ferramenta de invenção e, assim, condiz com uma atividade intelectual que precede a realização de uma invenção. Por meio do domínio dos conhecimentos de aritmética, geometria e técnicas de proporções, o desenho viabilizava qualquer intenção.

Nos séculos XVI a XVIII o conceito de desenho era bastante diferente do nosso atual, comportando a tripla conotação de raciocínio a priori (antevisão, predefinição, i.e., projeto), representação gráfica e, em linguagem figurada, desígnio. (BUENO, 2011, p. 26).

A partir desta concepção, foi desenvolvida toda uma convenção para o desenho dos engenheiros militares, com intuito de transmitir informações por meio de representações acerca do sítio, da região, do clima, dos habitantes, dentre outras de maneiras didáticas, a fim de serem reconhecidas em qualquer lugar. 
Decodificá-los implica em traduzir convenções e códigos gráficos e, ultrapassando este primeiro nível de aproximação, mergulhar nas entrelinhas das narrativas e discursos ali amalgamados, nem sempre óbvios e ricos em figuras de linguagem retórica. Para além de sua beleza aparente, fascinam tanto pelo que revelam como pelo o que ocultam. (BUENO, 2011, p.28).

Contudo, como desenhos militares, possuíam finalidades específicas. Logo, a representação de grandes extensões de território tornou-se inviável em um desenho com formas naturalistas. Desse modo, surgiu a necessidade de desenvolver um sistema de códigos e de convenções paisagísticas. Conforme a autora, tais padrões podem ser encontrados no tratado "O engenheiro Português (1729)", realizado por Manoel de Azevedo Fortes. Nele é prescrito que o engenheiro desenhador deve delinear o terreno e mostrar montes, vales, arvoredos, vinhas, terras lavradas, isto é, tudo que esteja presente na configuração geográfica do território. A autora faz referência à figura de convenções e códigos de Manoel de Azevedo, com o intuito de demonstrar as convenções empregadas no desenho paisagístico; nessa referência está presente como devem ocorrer os procedimentos para a configuração do desenho. A princípio, todo o desenho é traçado a lápis e somente depois ele é preenchido com tintas a partir das aguadas.

Em relação às paisagens do Ciclo de Miranda, Belluzzo e Piccoli (2003) constatam que estão próximas das linguagens dos geógrafos, uma vez que nelas são identificadas convenções de códigos cartográficos. Questão que pode ser visualizada principalmente na forma como fora empregada a perspectiva em suas paisagens, muito próxima a uma gama de documentos publicadas no mesmo período de produção das iconografias, como o tratado descrito anteriormente.

Em relação à perspectiva, Bueno (2011) esclarece que existem algumas formas de representação, "[...]a ichnographia (planta), orthographia (perfil) e scenographia (perspectiva militar)" (BUENO, 2011, p.107). A última forma é a que nos interessa, pois é nela que vemos a explicação sobre a perspectiva voo de pássaro, muito utilizada nos desenhos dos engenheiros militares, inclusive nos de Joaquim de Miranda. A Scenographia, além de ser denominada como militar, também é chamada de cavalheira, distinguindo-se das perspectivas rigorosas. Foi muito utilizada pelos engenheiros e, dentre as representações cenográficas, encontra-se a "vista de pássaro", na qual a paisagem é representada como vista do ar. Na maior parte das estampas temos esta impressão de observar as imagens do alto.

É interessante observar que, na gama de documentações coloniais produzidas por meio do desenho, quanto mais se consolidavam as convenções, mais escassas se tornavam as expressões livres e, por tal razão, no século XVIII há poucos desenhos no estilo cartográfico que ilustram personagens, sendo geralmente o foco paisagístico (BUENO, 2011).

Entretanto, o desenho como instrumento para a colonização é "[...] um veículo capaz de dar à coroa a medida de seu Império e materializar nas conquistas a presença de um rei

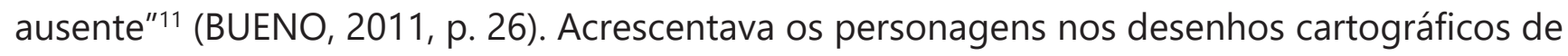
acordo com o intuito de sua realização e, por este motivo, foi conveniente na configuração 
das estampas o enfoque nos sujeitos envolvidos com a expedição, já que, ao que tudo indica, o relato teve como objetivo retratar o contato entre índios e militares.

Para Sevcenko (2003), as estampas foram produzidas junto com o relatório, com o propósito de transmitir um tratamento humano e cordial dos militares para com os indígenas que representassem a fidelidade do governo perante as prescrições da política indigenista de Pombal. Deste modo, as estampas de Miranda se destacam entre tais registros, constituindo uma exceção, pois focalizam nos personagens, principalmente nos corpos indígenas.

\section{CONSTRUÇÃO DA IMAGEM KAINGANG A PARTIR DO CORPO}

Destarte não podemos pensar na constituição da imagem do corpo indígena sem pensar na concepção histórica de corpo daquela dada circunstância, em específico na forma como os militares estavam observando os Kaingang a partir de propósitos específicos. A respeito da conjuntura portuguesa, Sevcenko (2003) afirma que Portugal adentrou de forma tardia na modernidade. No fim do século XVII e início do século XVIII, a Coroa encontra ouro no Sul do Brasil. Em meio aos tumultos desta descoberta, o contrabando, por meio da isenção do quinto estipulado como pagamento à Coroa, faz a monarquia portuguesa adquirir o monopólio da exploração, levando riquezas a todo o reinado de D. João V (1706-1750) em Portugal. Tal condição socioeconômica conduz "[...] a elite portuguesa a que desfrutava dos benefícios coloniais [...] a desfrutar de um estilo de vida suntuoso e exibitivo, centrado na corte e nas extravagâncias do próprio monarca" (SEVCENKO, 2003, p. 17). Em razão deste padrão social de extravagâncias, a Corte Portuguesa foi malvista por vários países da Europa, pois adentravam na "Era da Razão", início da ascensão do racionalismo e do projeto de modernidade.

Essa espantosa combinação de riqueza extrema, com luxo extravagante e devoção exacerbada, se foi ruinosa para as contas portuguesas, também não fez nenhum bem para a imagem do país na Europa. Em plena 'Era da Razão', em que o racionalismo em ascensão começava a penetrar até as Cortes absolutistas em que o pensamento econômico fixava os fundamentos que engendrariam a Revolução Industrial, Portugal era apresentado pelos iluministas como um exemplo acabado de tudo o que era oposto ao projeto da modernidade [...] capitalista. (SEVCENKO, 2003, p. 17).

Além disso, a Coroa portuguesa ainda estava relacionada com o clero e com as instituições católicas, o que também foi depreciado pela alta sociedade europeia. O autor aponta que, a partir da administração do novo monarca (D. José I. - 1750-1777), Marquês de Pombal assume o cargo de governador em 1755. Adepto do pensamento iluminista, elaborou um projeto de reforma na economia portuguesa a partir desta concepção.

Seu objetivo maior era produzir uma ampla reforma educativa e cultural no Reino, [...] estabelecendo um modelo de Estado leigo, baseado em premissas racionais, determinado a estimular a prosperidade econômica e a garantir a segurança de seus territórios, colônias e riquezas. (SEVCENKO, 2003, p. 17).

Portanto, vemos que a conjuntura histórica da expedição aos Campos de Guarapuava procedeu no momento em que Portugal passava por uma reforma econômica, baseada 
na concepção iluminista do governo de Pombal, sob o comando de Morgado de Mateus, governador da capitania de São Paulo, que provavelmente corroborava com o projeto racionalista moderno. Neste momento, apontamos como o corpo indígena era concebido para os comandantes da expedição, por meio da percepção lluminista europeia.

Embora na Europa ainda permaneça a sacralidade do corpo em função da igreja, com o desenvolvimento das ciências no século XVIII o corpo começa a ser objeto de racionalidade, incluindo-se nas políticas de Estado. Isso é o que Foucault (2008) denomina como biopoder, ou seja, a técnica política de investimento do Estado sob o corpo da população, investimento sob a saúde dos povos, que devem ser saudáveis para tornarem-se produtivos e úteis, e dentre as questões conseguirem defender os territórios de outros povos.

Neste cenário, houve a estratégia da Coroa em aproveitar os indígenas que habitavam nos sertões para fortalecer as fronteiras dos domínios espanhóis, estendendo-se as expedições aos Campos de Guarapuava e convergindo com a noção de biopoder.

Para alcançar essa finalidade, era necessário, nas palavras de Bellotto (2007), civilizar os índios. Portanto observamos, na leitura de Foucault, que civilizar compreende as formas múltiplas de como homens governam outros homens aplicando o poder disciplinar (OKSALA, 2011), isto é, "[...] um corpo que pode ser submetido, que pode ser utilizado, que pode ser transformado e aperfeiçoado [...]" (FOUCAULT, 1987, p. 118). O autor coloca que não é a primeira vez que o corpo é objeto de investimentos, que em qualquer sociedade o corpo está sujeito a limitações, proibições e obrigações. Foi no século XVIII, contudo, que as novas técnicas de poder sobre o corpo foram trabalhadas detalhadamente para exercer sobre ele uma coerção, a fim de mantê-lo ao nível da mecânica, tanto seus movimentos, gestos e rapidez. Seu controle consiste na economia e na eficácia dos movimentos, além de sua organização interna, na criação de métodos que implicam a imposição constante sobre os processos de atividades exercidos pelo corpo, ou seja, métodos que propiciam o controle minucioso das operações corporais "[...] que realizam a sujeição constante de suas forças e thes impõem uma relação de [...] utilidade, são o que podemos chamar as 'disciplinas' [...]" (FOUCAULT, 1987, p. 118). As disciplinas, ou os processos disciplinares, são vistos pelo autor em vários lugares, como nos exércitos e nos conventos, porém foi no decorrer dos séculos XVII e XVIII que se tornaram fórmulas gerais de dominação.

O momento histórico das disciplinas é o momento em que nasce uma arte do corpo humano, que visa não unicamente o aumento de suas habilidades, nem tampouco aprofundar sua sujeição, mas a formação de uma relação que no mesmo mecanismo o torna tanto mais obediente quanto é mais útil, e inversamente. Forma-se então uma política de coerções que são um trabalho sobre o corpo, uma manipulação calculada de seus elementos, de seus gestos, de seus comportamentos. (FOUCAULT, 1987, p. 119).

Como vimos na conjuntura das expedições, Morgado de Mateus foi designado como governador de São Paulo, encarregado pela militarização da capitania, portanto suas ações são em sua maioria de cunho militar, inclusive no que tange às expedições ao Tibagi e aos Campos de Guarapuava. Dessa forma, visualizamos que a imagem do corpo Kaingang foi construída 
a partir de um olhar militar, contendo um desígnio específico: observar e controlar os corpos indígenas para integrá-los à população portuguesa por meio do que Foucault denomina como biopoder. A própria autoria das imagens foi atribuída a um engenheiro militar, Joaquim José de Mirando. Sendo assim, vemos que a construção da imagem do Kaingang está permeada da perspectiva militar. Como constatamos, a Coroa Portuguesa pretendia em seus planos utilizar os indígenas que habitavam os sertões, no caso os Kaingang dos Campos de Guarapuava, para fortalecer as fronteiras dos domínios espanhóis, tendo em vista civilizá-los, nas palavras de Sevcenko (2003), educá-los, no português, "adestrá-los", da mesma maneira que disciplinava seus militares. Questão que Morgado de Mateus procurou seguir durante as expedições aos Campos, isto é, ter o intuito de amansar a hostilidade dos Kaingang.

Contudo, tal intento não foi alcançado, visto que no próprio documento as iconografias da décima expedição retratam a falha desta campanha. Isso porque os Kaingang resistiram a ocupação dos militares nos Campos. Dessa maneira, por meio de bons tratos, os militares pretendiam disciplinar os corpos indígenas. No relatório que acompanha as iconografias, o coronel Botelho estabelece aos expedicionários que os indígenas deveriam ser tratados com afabilidade, mimos, e que os militares deveriam capacitá-los a serem amigos, ou seja, moldar o comportamento dos indígenas para serem aliados de Portugal. Para tal, os militares iniciaram o contato com os Kaingang se aproximando, procurando ganhar a confianças desses índios. Assim, visualizamos que as ações dos militares durante as expedições estão inseridas nas concepções de corpo do momento histórico das disciplinas exposto por Foucault, visando ao processo de disciplina do corpo, já que "[...] visa não unicamente o aumento de suas habilidades, nem tampouco aprofundar sua sujeição, mas a formação de uma relação que no mesmo mecanismo o torna tanto mais obediente quanto é mais útil [...]" (FOUCAULT, 1987, p. 119). No caso das expedições, tratar os Kaingang com "mimos e afabilidade" significa buscar dominálos e torná-los mais úteis em favor dos interesses da Coroa, especificamente em proveito das pretensões do governador Morgado de Mateus, para adquirir credibilidade com Portugal.

Na realidade, como já observado em Bellotto (2007), os planos tanto da Coroa como de Morgado de Mateus convergiam para que as populações indígenas pudessem compor força de ataque contra os espanhóis e, com isso, uma possível militarização ${ }^{12}$ dos corpos indígenas. Em muitos momentos das descrições de Botelho e nas iconografias do Ciclo de Miranda, visualizamos que o olhar militar estava voltado para a constituição física dos índios Kaingang e sua possível transformação para os propósitos dos expedicionários, como vimos na primeira sequência que compõe as estampas, a ilustração somente dos Kaingang isolados, retratos dos indígenas adultos que encontraram nos Campos de Guarapuava, tanto homens como mulheres. Perante o apelo visual destas figuras descritas no tópico referente, identificamos a intencionalidade dos expedicionários: descrevê-los e visualizá-los, e o empenho da expedição em classificar e identificar os habitantes dos Campos de Guarapuava, de acordo com a função do desenho realizado pelos engenheiros militares a serviço do processo de colonização. Ou seja, os militares estão procedendo como exige a disciplina do exército no século XVIII, a 
princípio individualizando os sujeitos que pretendem reconhecer, classificar, ordenar e, por final, dominá-los. Ao isolar os indivíduos, favorece a sua identificação e descrição.

A procedência dos militares vista na expedição também está relacionada com a modificação da composição de forças bélicas na Europa do século XVIII. Foucault (1987) explica que, até o século XVII, a tropa era utilizada somente de duas formas, ou como projétil ou como fortaleza, visto que a divisão dos soldados ocorria segundo a sua antiguidade e valentia. Diante de um ataque, a localização dos soldados era previsível: no centro, os que fariam volume e peso e que davam densidade ao corpo; os mais novos na frente; e nos ângulos os soldados com maiores reputações. No século XVIII, entretanto, a divisão dos soldados torna-se mais complexa, uma espécie de máquina de peças múltiplas, um jogo de articulações minuciosas, que se desloca em relação umas às outras para chegar a uma configuração que leve a um resultado específico. Além das razões econômicas que levaram a esta mudança, pois torna útil e rentável a manutenção cada indivíduo, tal transformação também ocorreu a partir de uma técnica, a invenção do fuzil, que valorizava a habilidade do soldado.

Portanto, as estratégias bélicas foram reconfiguradas com a finalidade de encontrar uma tática calculável, tanto das localizações individuais e coletivas dos soldados, como no deslocamento de grupos e também dos elementos isolados e das mudanças de posições. $O$ princípio das novas táticas bélicas é pensar nos segmentos divisíveis, já que, a partir de então, surge uma nova exigência ao pensamento disciplinar: "A disciplina não é mais simplesmente uma arte de repartir os corpos, de extrair e acumular o tempo deles, mas de compor forças para obter um aparelho eficiente" (FOUCAULT, 1987, p. 138).

Deste modo, constatamos a estratégia do governador de São Paulo em utilizar e disciplinar a população Kaingang em sua política de incorporação e ocupação da Região Sul, isto é, a pretensão de que os indígenas iriam compor forças a favor da Coroa Portuguesa. $O$ que significa que a ênfase atribuída aos personagens do Ciclo de Mirando, em especial na população indígena, demonstra a constituição de parte da estratégia de ocupação colonial Portuguesa contra a ameaça espanhola nos territórios brasileiros, tendo em vista auxiliarem no estabelecimento do povoamento na região do Tibagi e Campos de Guarapuava. Deste modo, seus corpos ocupavam um local específico na tática bélica, a fim de serem incorporados à população portuguesa para somar forças contra o inimigo.

\section{CONSIDERAÇÕES FINAIS}

A perspectiva militar a partir da noção disciplinar de corpo permeou a política colonial portuguesa empregada nos territórios brasileiros, especificamente quando Pombal assume o governo português em meados do século XVIII. O corpo Kaingang é visto por Morgado como ponto de uma estratégia bélica contra os espanhóis, tendo em vista utilizar as populações indígenas para o fortalecimento e estabelecimento do domínio português no território brasileiro. Aproveitar os indígenas que habitavam nos sertões para fortalecer as fronteiras 
dos domínios espanhóis, a fim de que constituíssem a principal força e riqueza de defesa das fronteiras portuguesas, estava nos Planos de Pombal a princípio, isto é, o governador tinha o intuito de civilizar os índios e trazê-los em favor de Portugal. Portanto, objetivava aumentar sua força de combate e o número de súditos da Coroa, multiplicando seu poder num todo, agregando paulistas e indígenas em um mesmo propósito. Sevcenko (2013) ainda esclarece que, com isso, Pombal pretendia aplicar uma defesa política a partir da ocupação populacional de "soldados-colonos" nas áreas vulneráveis do território brasileiro, considerando a ideia de que uma das riquezas de todos os países consiste no número de multiplicação da população que o habita. Assim, os indígenas faziam parte desta estratégia do aumento da população portuguesa. Para tal, era necessário educá-los no português, "adestrá-los" e misturá-los, casando-os com europeus.

\section{REFERÊNCIAS}

ANAIS DA BIBLIOTECA NACIONAL. Notícia da Conquista e descobrimento dos sertões do Tibagi. Rio de Janeiro: Biblioteca Nacional, 1956. v. 76.

BELLOTTO, H. Autoridade e conflito no Brasil colonial: o governo do Morgado de Mateus em São Paulo (1765-1775). São Paulo: Alameda, 2007.

BELLUZZO, A.; PICCOLI, V. Desenho e conquista territorial. In: BELLUZZO, A. M. de M. et al. Do contato ao confronto: a conquista de Guarapuava no século XVIII. São Paulo: BNP Paribas, 2003. p. 44-53.

BOSI, A. Reflexões sobre a arte. 7. ed. São Paulo: Ática, 2000.

BOTELHO, A. Notícia da conquista e descobrimento dos sertões do Tibagi. Rio de Janeiro: Biblioteca Nacional, 1956. v. 76. Anais da Biblioteca Nacional.

BUENO, B. Desenho e desígnio: o Brasil dos engenheiros militares (1500-1822). São Paulo: Ed. da Universidade de São Paulo: Fapesp, 2011.

FOUCAULT, M. Vigiar e punir: nascimento da prisão. Petrópolis, RJ: Vozes, 1987.

MOTA, L. As guerras dos índios Kaingang: a história épica dos índios Kaingang no Paraná (1769-1924). 2. ed. Maringá: Eduem, 2009.

MOTA, L.; NOVAK, E. S. Os Kaingang do Vale do Rio Ivaí-PR: história e relações interculturais. Maringá: Eduem, 2008.

OKSALA, J. Como ler Foucault. Rio de Janeiro: Zahar, 2001.

SEVCENKO, N. O ciclo de Miranda: utopia indigenista no Brasil pombalino. In: BELLUZZO, Ana Maria de Moraes et al. Do contato ao confronto: a conquista de Guarapuava no século XVIII. São Paulo: BNP Paribas, 2003. p.15-23. 
1 BOTELHO, A. Notícia da Conquista e descobrimento dos sertões do Tibagi. Rio de Janeiro: Biblioteca Nacional, 1956. v. 76. Anais da Biblioteca Nacional.

2 De acordo com Belluzzo e Piccoli (2003), a rainha referida incide em D. Maria I, rainha de Portugal. Além disso, as autoras apontam que, provavelmente, o documento seja posterior a sua coroação, ocorrida em 1777.

3 Tenente-coronel da infantaria da Praça de Santos e comandante das ditas expedições.

4 Para mais informações históricas, ir ao segundo nível de análise deste capítulo, no tópico 3.3. Segundo Olhar: Contexto material da produção iconográfica.

5 Denominação atribuída por Sevcenko (2003), diz respeito às iconografias que acompanham o documento da expedição de Morgado de Mateus ou seus associados realizaram, nomeada de "Notícia da Conquista e Descobrimento dos Sertões do Tibagi", de 1768 à 1774. 6 ANAIS DA BIBLIOTECA NACIONAL. Notícia da Conquista e descobrimento dos sertões do Tibagi. Rio de Janeiro: Biblioteca Nacional, v. 76, 1956.

7 Todas as imagens contidas neste tópico são referentes às estampas de autoria de Joaquim José de Miranda, século XVIII, Guache e Aquarela, 42,5 x $55 \mathrm{~cm}$. Fonte: Belluzzo et al. (2003). Contém esta mesma legenda referente às questões técnicas de suas produções. Por esta razão, não repetimos tais legendas nas estampas seguintes.

8 Botelho (1956, p. 28).

9 É caracterizada por Balandier (1993) como uma situação complexa e dinâmica que engloba europeus e nativos (africanos e ameríndios) em um contexto de ampla expansão do capital, sendo permeado de estratégias, alianças e adaptações.

10 Em Bosi (2000), vemos que foi a partir da Renascença italiana que se passou a ter um interesse matemático das artes visuais em relação ao espaço, com ênfase na proporção e na perspectiva.

11 A autora explica que os reis "portugueses" não se deslocavam pelo seu império, no caso o Brasil. Por meio dos mapas, contudo, materializavam as ocupações do seu reinado, tanto os edifícios, as vilas e as cidades. Por esta razão, Bueno (2011) recortou o segundo capítulo deste livro em reinados portugueses, os quais começam em D. João II (1481-1495) e vão até D. João $V(1706-1750)$.

12 Nas políticas indigenistas posteriores os militares continuaram a ter a função de pacificar os índios e conquistarem terras. Questão vista no SPI. Lima (1992) aponta que o SPI foi criado em 1910 como Serviço de Proteção aos índios e Localização de Trabalhadores Nacionais (SPILTN), constituindo parte do Ministério da Agricultura e Indústria e Comércio, e pretendia fixar no campo mão de obra rural que não fosse estrangeira, a partir do treinamento técnico de força de trabalho realizado nas unidades de ação e centros agrícolas. Isto é, o SPILTN tinha a função de atrair, pacificar e conquistar as terras sem destruir seus habitantes indígenas, para adquirir mão de obra necessária com a finalidade de utilizar as populações aclimatadas aos trópicos, no caso os indígenas, para desbravar e preparar as terras não colonizadas, para posterior ocupação dos fog. No quadro dos SPILTN continha, em sua maioria, a presença de militares, principalmente em sua direção. Nesse momento, ocorreu efetivamente uma disciplinarização do corpo indígena a partir da noção militar, por meio do trabalho rural. 